\title{
Isolation and Characterization of the Sheath from the Cyanobacterium Chlorogloeopsis PCC 6912
}

\author{
By MICHAEL SCHRADER, GERHART DREWS, \\ JOCHEN R. GOLECKI AND JÜRGEN WECKESSER* \\ Institut für Biologie 2, Mikrobiologie, der Albert-Ludwigs-Universität, Schänzlestrasse 1, \\ D-7800 Freiburg i. Br., Federal Republic of Germany
}

(Received 19 March 1981; revised 24 June 1981)

\begin{abstract}
A sheath fraction was isolated from cells of the cyanobacterium Chlorogloeopsis PCC 6912. It had a fibrillar fine structure, a high density and contained $38 \%(\mathrm{w} / \mathrm{w})$ carbohydrates and $22 \%(w / w)$ protein. Glucose, mannose, galactose, arabinose, xylose, an unknown sugar and glucuronic acid were the major carbohydrates. Lipids were almost entirely absent. The protein was not solubilized by treatment with hot phenol/water $\left(68^{\circ} \mathrm{C} ; 20 \mathrm{~min}\right)$ or Triton $\mathrm{X}-100\left(2 \%, \mathrm{w} / \mathrm{v} ; 20^{\circ} \mathrm{C} ; 3 \mathrm{~h}\right)$. The carbohydrates of the sheath belong to two different polysaccharides. The major one was not separated from the protein moiety of the sheath by hot phenol/water. It contained glucose as the main constituent, arabinose and xylose but little galactose, in addition to the other carbohydrates. In contrast, the minor polysaccharide was soluble in the water phase of hot phenol/water extracts and contained galactose as a major constituent in addition to glucose and mannose, but very little arabinose and xylose. The polysaccharide enriched in galactose could also be obtained from the water phase by precipitation with Cetavlon when sheath-containing whole cells were extracted by phenol/water.
\end{abstract}

\section{INTRODUCTION}

The heterocyst-forming cyanobacterium (blue-green alga) Chlorogloeopsis (synonym Chlorogloeopsis fritschii, Chlorogloea fritschii) can grow as different morphological types (Mitra, 1950; Evans et al., 1976). After germination of the akinetes, the different types, including short trichomes and multicellular clusters of cells having different sizes and various planes of cross-septa, are observed in an ordered sequence (Rippka et al., 1979). Batch cultures contain a mixture of the cell types; culture conditions influence the process of differentiation (Evans et al., 1976).

The cell wall of Chlorogloeopsis is of the Gram-negative type as demonstrated by electron microscopy (Peat \& Whitton, 1967; Findley et al., 1970). Single cells or cell clusters are surrounded by an additional layer, the sheath, which can be seen with a light microscope. Ultra-thin sections of the sheath show osmiophilic lamellae, oriented more or less parallel to the cell wall (Peat \& Whitton, 1967; Findley et al., 1970). Cells grown at high light intensity form more sheath material than those grown under low light conditions (Findley et al., 1970). Sheath material is shed from the cells as is readily observed on germination of akinetes (Rippka et al., 1979). The present paper describes the isolation, fine structure and composition of the sheath of Chlorogloeopsis PCC 6912.

\section{METHODS}

Organism and growth conditions. Chlorogloeopsis PCC 6912 (from the Pasteur Culture Collection, Paris, France) was used throughout the study. Cells were grown photoautotrophically at $35^{\circ} \mathrm{C}$ in 101 carboys, 
irradiated continuously with white light from a fluorescence lamp (1-4 klx) and gassed with air containing 5\% $\mathrm{CO}_{2}$. A modified Jüttner medium (Schmidt et al., 1980) containing a threefold nitrate concentration was used. Cells were collected after 10-14 d. At this stage, cultures had a green-yellow appearance and most of the cells were of the aseriate type. Associations of 2-16 cells and akinetes (see Fig. 2 in Evans et al., 1976) were observed. Filamentous forms were only occasionally present. Cells were suspended in distilled water using a Potter vessel and were washed several times with distilled water by low speed centrifugation $(160 \mathrm{~g}, 15 \mathrm{~min})$.

Isolation of the sheaths. Cells were suspended in $10 \mathrm{~mm}$-Tris $/ \mathrm{HCl}$ buffer, $\mathrm{pH} 7.8$, containing $1 \mathrm{mM}$-EDTA and $1 \mathrm{mM}-\mathrm{NaN}_{3}$, and were homogenized by shaking with glass beads (diameter $0.25 \mathrm{~mm}$ ) for 10 min at $4{ }^{\circ} \mathrm{C}$ in a Braun disintegrator (type MSK; Braun, Melsungen, F.R.G.). Two centrifugations at $160 \mathrm{~g}$ for $30 \mathrm{~min}$ separated the heavy sheaths from the supernatant cell debris. A continuous gradient of sucrose $(40-60 \%, \mathrm{w} / \mathrm{w} ; 600 \mathrm{~g} ; 50 \mathrm{~min})$ or $\mathrm{CsCl}(4.5 \mathrm{M} ; 4000 \mathrm{~g} ; 30 \mathrm{~min})$ was used twice for further purification. Sucrose and $\mathrm{CsCl}$ were removed by dialysis against distilled water before lyophilization of the sheaths. Light microscopy showed that sheath material was nearly free of cell material.

Phenol/water and Triton X-100 extraction. Lyophilized cells or the sheaths were extracted with phenol/water at $68^{\circ} \mathrm{C}$ for $20 \mathrm{~min}$ as described by Schrader et al. (1982) or treated with Triton X-100 (2\%, v/v, in water; $20^{\circ} \mathrm{C}$; $3 \mathrm{~h})$.

Fractionation by Cetavlon. The water phase of phenol/water extracts from whole cells was centrifuged at $105000 \mathrm{~g}$ for $4 \mathrm{~h}$ and the supernatant was subjected to a Cetavlon (cetyltrimethylammonium bromide) fractionation according to Westphal \& Jann (1965).

Pronase treatment. The sheath fraction was incubated for $6 \mathrm{~h}$ with pronase (EC 3.4.24.4, from Streptomyces griseus; Serva, Heidelberg, F.R.G.) at a concentration of $1 \mathrm{mg}$ per $50 \mathrm{mg}$ protein in $1 \mathrm{mM}$-Tris/HCl buffer, $\mathrm{pH}$ 7.4 , at $37^{\circ} \mathrm{C}$. Bovine serum albumin was used as the standard. The solubilized protein was precipitated with trichloroacetic acid $(50 \mu \mathrm{g}$ per $800 \mu \mathrm{l}$ final concentration) and separated by centrifugation. Protein was determined by the Lowry method.

Electron microscopy. Fixation of whole cells or sheath fraction in $2 \%(\mathrm{v} / \mathrm{v})$ glutaraldehyde and $1 \%(\mathrm{w} / \mathrm{v}) \mathrm{OsO}_{4}$, dehydration in alcohol and polymerization in Epon as well as preparation of ultra-thin sections have been described elsewhere (Golecki, 1977). Cells for freeze-fracture preparation were quickly frozen in Freon 22 and freeze-fractured by standard methods in a Balzers 360 MA apparatus with an etching time of 1 min at $-100^{\circ} \mathrm{C}$. The specimens were examined in a Philips EM 400 or a Siemens Elmiskop IA microscope operating at $80 \mathrm{kV}$.

Chemical analyses. Hydrolysis of carbohydrates and polypeptides and the determination of monomers have been described elsewhere (Schmidt et al., 1980). Neutral sugars were identified by thin-layer chromatography (solvent: ethyl acetate/pyridine/water; $12: 5: 4$, by vol.) and by gas-liquid chromatography as alditol acetate derivatives (Varian Aerograph, model 1445-1, ECNSS-M column, 3\% on GasChrom Q, 100-120 mesh). Amino sugars and amino acids were separated and quantitatively determined on an automatic amino analyser (Durrum, model D-500). Fatty acids were studied as methyl esters by gas-liquid chromatography (EGSS-X column, $15 \%$ on GasChrom P, 100-200 mesh; or Castorwax column, 2.5\% on Chromosorb G, 80-100 mesh). Organic phosphorus was determined according to Lowry et al. (1954). Uronic acids, detected on high voltage paper electropherograms by staining with alkaline silver nitrate (Schmidt et al., 1980), were quantitatively determined by the colorimetric carbazole assay at $530 \mathrm{~nm}$. Since the neutral sugars mannose, galactose and glucose interfere in this test, their effect was quantitatively determined using known concentrations of each sugar in the carbazole assay. The value of the interfering absorbance was subtracted from the value determined with the sheath or polysaccharide fractions.

\section{RESULTS}

\section{Isolation and fine structure of the sheath}

The isolation and purification was facilitated by the relatively high density of sheath material. The sheath fraction was obtained by low speed centrifugation of the cell homogenate and purified by sucrose density gradient centrifugation. Between $20 \%$ and $30 \%$ of the cell mass was obtained as the sheath fraction. The lack or negligible content of meso-diaminopimelic acid, muramic acid and 6-O-methyl-D-mannose, which are components of the cell wall (Schrader et al., 1982), indicated that the sheath fraction was free of cell wall material.

In ultra-thin sections (Fig. 1a), the isolated sheath fraction showed a homogeneous fibrillar fine structure. The shape of the cell was essentially retained. Freeze-etching of whole cells confirmed an orientation of the fibrillar material parallel to the cell wall and showed fine structural homogeneity of the sheath in situ (Fig. $1 b$ ). 


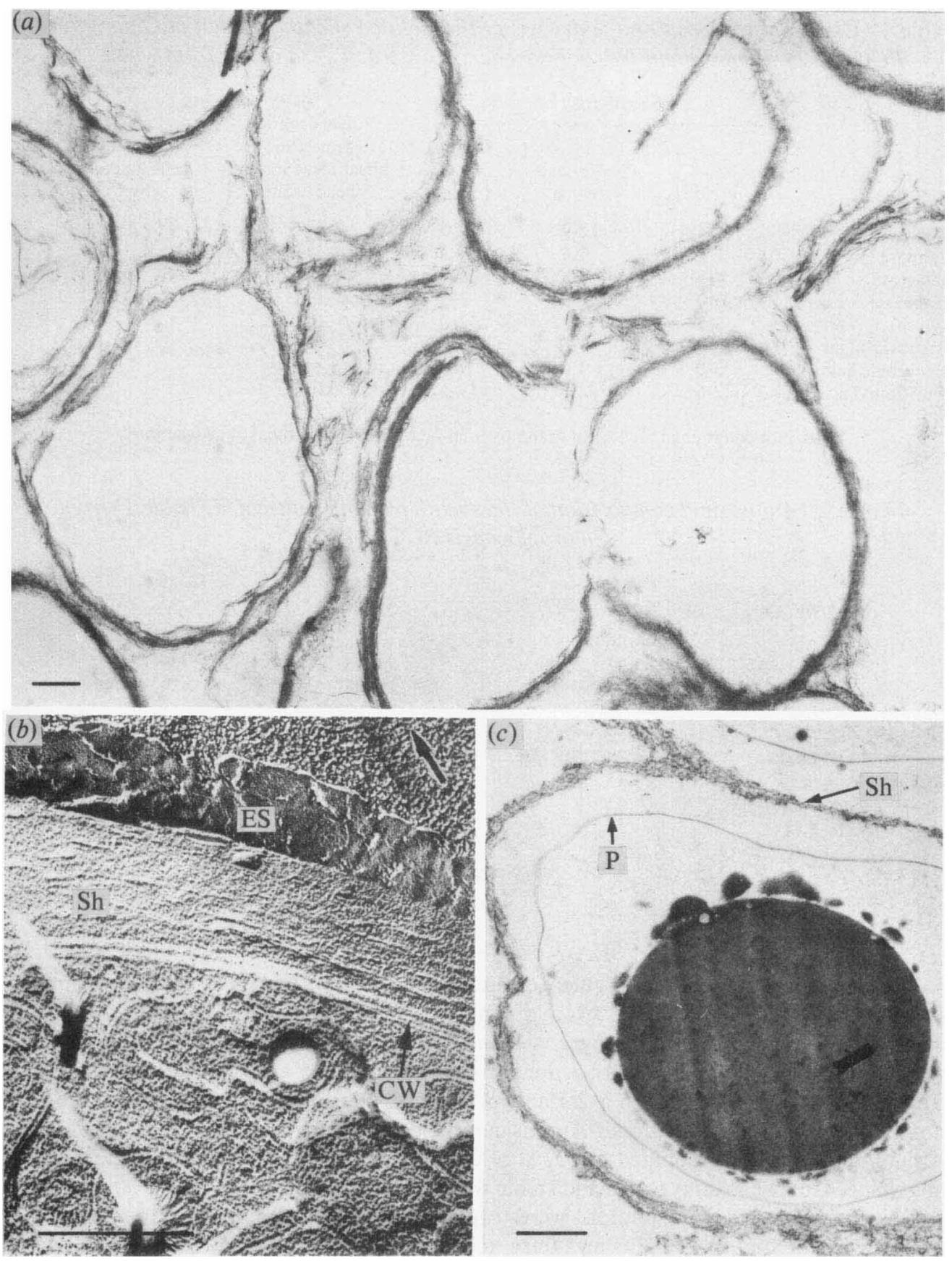

Fig. 1. (a) Ultra-thin section of isolated sheath material, shed from Chlorogloeopsis PCC 6912 cells by mechanical means. (b) Freeze-etch preparation of Chlorogloeopsis PCC 6912 cells. Note that the sheath (Sh) looks homogeneous in fine structure. CW indicates the cell wall and ES indicates the exoplasmic surface of the sheath. The arrow in the upper right corner indicates the direction of shadowing. (c) Ultra-thin section of Chlorogloeopsis PCC 6912 cells extracted by hot phenol/water prior to fixation and embedding. The outer membrane of the cell wall and the cytoplasmic membrane are no longer present but the sheath $(\mathrm{Sh})$ and the peptidoglycan layer (P) are still visible. The bar markers represent $0.5 \mu \mathrm{m}$. 
Table 1. Chemical composition (\% dry wt) of the isolated sheath fraction of Chlorogloeopsis PCC 6912 and of protein-free polysaccharides extracted from it or from whole cells

\begin{tabular}{|c|c|c|c|c|c|}
\hline \multirow[b]{2}{*}{ Constituent } & \multicolumn{3}{|c|}{ Sheath fraction } & \multirow{2}{*}{$\begin{array}{l}\text { Polysaccharide } \\
\text { extracted from the } \\
\text { sheath fraction by } \\
\text { phenol/water }\end{array}$} & \multirow{2}{*}{$\begin{array}{c}\text { Polysaccharide } \\
\text { extracted from whole } \\
\text { cells and precipitated } \\
\text { by Cetavlon }\end{array}$} \\
\hline & Untreated & $\begin{array}{c}\text { Phenol/water } \\
\text { treated }\end{array}$ & $\begin{array}{l}\text { Triton } \\
\mathrm{X}-100 \\
\text { treated }\end{array}$ & & \\
\hline Glucose & $14 \cdot 4$ & 12.9 & $19 \cdot 0$ & $7 \cdot 2$ & $12 \cdot 3$ \\
\hline Mannose & $7 \cdot 2$ & $3 \cdot 6$ & $5 \cdot 3$ & $6 \cdot 2$ & 9.9 \\
\hline Galactose & $4 \cdot 8$ & 1.8 & $6 \cdot 7$ & $8 \cdot 7$ & $18 \cdot 9$ \\
\hline Arabinose & $3 \cdot 0$ & $2 \cdot 5$ & $3 \cdot 3$ & 0.3 & $1 \cdot 2$ \\
\hline Xylose & $3 \cdot 2$ & $2 \cdot 1$ & 2.0 & 0.2 & 0.6 \\
\hline Unknown sugar & 2.7 & 1.6 & ND & ND & $4 \cdot 0$ \\
\hline Glucuronic acid & 3.0 & $4 \cdot 0$ & ND & ND & $14 \cdot 0$ \\
\hline Total amino acids & 22.6 & $22 \cdot 9$ & 19.6 & 0.9 & - \\
\hline
\end{tabular}

ND, Not determined. Traces of rhamnose and fucose were also found in all fractions.

Table 2. Amino acid composition of the sheath fraction (untreated, Table 1) from Chlorogloeopsis PCC 6912

$\begin{array}{cccc}\text { Amino acid } & \begin{array}{c}\text { Content } \\ \text { (mol } \%, \text { Ala }=100)\end{array} & \text { Amino acid } & \begin{array}{c}\text { Content } \\ \text { (mol \%, Ala = 100) }\end{array} \\ \text { Ala } & 100 & \text { Thr } & 52 \\ \text { Glu } & 73 & \text { Pro } & 39 \\ \text { Asp } & 124 & \text { Ile } & 34 \\ \text { Leu } & 75 & \text { Met } & 8 \\ \text { Gly } & 153 & \text { Phe } & 29 \\ \text { Lys } & 34 & \text { Tyr } & 50 \\ \text { Ser } & 75 & \text { Cys } & \text { ND } \\ \text { Val } & 35 & \text { Trp } & \text { ND } \\ \text { Arg } & 58 & \text { His } & 3\end{array}$

ND, Not determined.

\section{Chemical analyses}

The sheath fraction contained glucose, mannose, galactose, arabinose, xylose and traces of rhamnose and fucose (Table 1$)$. An additional, unidentified sugar $\left(R_{\text {Gluctol acetate }}=1.9\right)$ was detected on gas-liquid chromatographic analysis of the neutral sugar hydrolysate. Mass spectrometric fragmentation of its deuterium-labelled, reduced alditol acetate showed a main fragment at $m / e 111$ indicating a 2,5-anhydro-hexose (Jansson et al., 1979). Glucuronic but not galacturonic acid was found. A considerable portion of the sheath consisted of protein. Amino acid residues accounted for $22 \%$ of the dry weight. A characteristic high proportion of glycine, aspartic acid, tyrosine and serine was observed (Table 2).

Glucosamine and phosphorus were present in trace amounts $(0.1 \%$ and $0.6 \%$, respectively, of the dry weight) and fatty acids, mainly palmitic acid, represented less than $0.5 \%$.

The protein portion of the sheath was slowly degraded by pronase $(0.25 \%$, minimal value, in 70 min under the experimental conditions given in Methods).

\section{Extraction by phenol/water or Triton X-100}

Most of the sheath fraction was found to be insoluble on extraction with hot phenol/water. Only $10 \%$ of the material was found in the water phase and about $2 \%$ in the phenol phase. In ultra-thin sections of phenol/water-extracted whole cells (Fig. 1c), the sheath was still present 
while the outer membrane and the cytoplasmic membrane were completely dissolved. The sugar and amino acid patterns of the sheath fraction before and after treatment with hot phenol/water were similar, except for a significant decrease in the galactose and mannose content (Table 1). The extraction procedure did not remove the protein.

Similarly, treatment of the sheath fraction with Triton X-100 (see Methods) removed about $15 \%$ of the dry weight without change of the gross composition.

\section{Protein-free polysaccharide}

The small amount of material extracted into the water phase by phenol/water treatment of the sheath fraction was nearly protein-free and had a composition different from the major polysaccharide fraction (Table 1). Galactose was the major constituent in addition to glucose and mannose, and the pentose content was low. This galactose-enriched polysaccharide was also extractable from the sheath-containing whole cells by hot phenol/water and could be precipitated from the respective water phase by the cationic detergent Cetavlon in $\mathrm{NaCl}$ $(0.3 \%$ Cetavlon in $75 \mathrm{~mm}-\mathrm{NaCl})$. These concentrations of the detergent and $\mathrm{NaCl}$ are known to precipitate acidic capsular polysaccharides of bacteria (Westphal \& Jann, 1965). The fatty acid, amino sugar and phosphorus contents were negligible in the protein-free polysaccharide fraction.

\section{DIS CUS SION}

Two properties of the sheath of Chlorogloeopsis PCC 6912 facilitated its isolation. First, it was shed from the cells by mechanical stress, and second, it had a high density. The shape and fibrillar fine structure of the sheath were retained after isolation. We do not know, however, whether the sheath fraction represented the complete sheath. The loosening of sheath structure in the isolated sheath compared with the original state might be due to the mechanical treatment. The freeze-etch studies revealed fine structural homogeneity throughout the whole sheath, although, in ultra-thin sections, the outermost regions of the sheath appeared to be less densely packed than those adjacent to the cell wall (Peat \& Whitton, 1967; Findley et al., 1970).

A heteropolysaccharide represented the main portion of the sheath fraction. Its composition, except for the galactose content, was little changed even when drastic methods were used for purification, such as hot phenol/water or Triton X-100. Interestingly, the protein moiety present in the sheath fraction was not removed by the extractions either. A relatively high glycine content found in this protein was also described for a protein of the exine from Azotobacter vinelandii (Lin \& Sadoff, 1968). Similarly, the exine has a multi-layered fine structure and contains carbohydrate. The exine of $A$. vinelandii, however, contains a major lipid portion which was absent from the sheath fraction of Chlorogloeopsis PCC 6912.

A protein-free polysaccharide with a similar composition but a higher relative galactose and lower arabinose and xylose contents compared with the phenol/water-insoluble fraction represented a minor component of the sheath fraction and could also be extracted from whole cells.

Since cultures used for the present study were not synchronized, it is not clear whether the sheath fraction belongs to a distinct cell type of Chlorogloeopsis PCC 6912. Single cells, trichomes, clusters of cells or akinetes have all been observed to be surrounded by sheath material.

The authors thank Mrs E. Metz for gas-liquid chromatographic analyses and R. Warth for amino acid and amino sugar analyses. The work was supported by the Deutsche Forschungsgemeinschaft. 


\section{REFERENCES}

Evans, H., Foulds, I. \& Carr, N. G. (1976). Environmental conditions and morphological variation in the blue-green alga Chlorogloea fritschii. Journal of General Microbiology 92, 147-155.

Findley, D. L., Walne, P. L. \& Holton, R. W. (1970). The effects of light intensity on the ultrastructure of Chlorogloea fritschii Mitra grown at high temperature. Journal of Phycology 6, 182-188.

GoleCKI, J. R. (1977). Studies on ultrastructure and composition of the cell walls of the cyanobacterium Anacystis nidulans. Archives of Microbiology 114, 35-41.

JANSSON, P.-E., KenNe, L., LiedGren, H., LindBERG, B. \& LöNNGREN, I. (1979). A practical guide to the methylation analysis of carbohydrates. Chemical Communications, University of Stockholm 8, 1-75.

LIN, L. P. \& SAdofF, H. L. (1968). Encystment and polymer production by $A$ zotobacter vinelandii in the presence of $\beta$-hydroxybutyrate. Journal of Bacteriology 95, 2336-2343.

LOWRY, O. H., Roberts, N. R., LEINER, K. Y., Wu, M. L. \& FARR, A. L. (1954). The quantitative histochemistry of the brain. I. Chemical methods. Journal of Biological Chemistry 207, 1-17.
Mitra, A. K. (1950). Two new algae from Indian soils. Annals of Botany 14, 457-464.

Peat, A. \& Whitton, B. A. (1967). Environmental effects on the structure of the blue-green alga, Chlorogloea fritschii. Archiv für Mikrobiologie 57, 155-180.

Rippka, R., Deruelles, J., Waterbury, J. B., Herdman, M. \& StanieR, R. Y. (1979). Generic assignments, strain histories and properties of pure cultures of cyanobacteria. Journal of General Microbiology 111, 1-61.

Schmidt, W., Drews, G., Weckesser, J., Fromme, I. \& Borowiak, D. (1980). Characterization of the lipopolysaccharides from eight strains of the cyanobacterium Synechococcus. Archives of Microbiology 127, 209-215.

Schrader, M., Drews, G., Weckesser, J. \& MAYer, H. (1982). Polysaccharide containing 6-O-methylD-mannose in Chlorogloeopsis PCC 6912. Journal of General Microbiology 128, 273-277.

WestPhal, O. \& JANN, K. (1965). Bacterial lipopolysaccharides. Extraction with phenol-water and further applications of the procedure. Methods in Carbohydrate Chemistry 5, 83-91. 